\title{
Agronomic Efficiency of Hybrids of Corn to Nitrogen, Phosphorus and Potassium Targeting Fresh Corn
}

\author{
Cecília L. P. Resende ${ }^{1}$, Leandro F. Damaso ${ }^{1}$, Mylla C. R. Ávila ${ }^{2}$, Daniel D. C. Carvalho ${ }^{1}$, \\ Patrícia G. S. Melo ${ }^{2} \&$ Fabricio Rodrigues ${ }^{1}$ \\ ${ }^{1}$ Universidade Estadual de Goiás, Campus Ipameri, Ipameri, Goiás, Brazil \\ ${ }^{2}$ Universidade Federal de Goiás, Campus Samambaia, Goiânia, Goiás, Brazil \\ Correspondence: Fabricio Rodrigues, Universidade Estadual de Goiás, Campus Ipameri, Ipameri, Goiás, Brazil. \\ Tel: 55-643-491-1556. E-mail: fabricio.rodrigues@ueg.br
}

Received: March 12, 2019

Accepted: April 24, $2019 \quad$ Online Published: June 30, 2019

doi:10.5539/jas.v11n9p120

URL: https://doi.org/10.5539/jas.v11n9p120

\begin{abstract}
The efficiency and responsiveness agronomic to the main macronutrients is becoming increasingly important due to the risk of supply, since it is a finite resource. In addition, excess fertilizer decreases the quality of water and air. Thus, the objective of this work was to assess the corn hybrids in terms of their efficiency and responsiveness to nitrogen $(\mathrm{N})$, phosphorus $(\mathrm{P})$ and potassium $(\mathrm{K})$, and identify the ones most suitable for fresh consumption, according to the product type and technological level to be adopted by the farmer. The randomized complete block design in a $10 \times 3$ (hybrids and doses) factorial scheme was adopted for the experiment, with three replications, for two season crops (2013/14 and 2014/15). Ten hybrids (2B512PW, 2B587PW, 2B707PW, 30F35HR, 30F53YH, AG1051, BRS1055, BM3061, P3646H e P3862YH) were used in isolation under low availability (without application) and partial, of $\mathrm{N}, \mathrm{P}$ and $\mathrm{K}$, in an isolated manner, also evaluated under the recommended dose, aiming at fresh consumption. The most efficient and responsive hybrid must first be identified in isolation, based on the availability it is subjected to and later, by its sale, focused on fresh consumption. The hybrids indicated for low availability (low technological level) were BRS1055 and 30F53YH, with respect to responsiveness or agronomic efficiency, the hybrid $\mathrm{P} 3862 \mathrm{YH}$ was the one that presented the best performance and indicated for technological levels of medium to high, considering the classification obtained for the nitrogen, phosphorus, and potassium for production vegetable corn.
\end{abstract}

Keywords: Zea mays L., nutritional efficiency, unhusked ears, commercial ears, fresh corn

\section{Introduction}

Agricultural fertilizers raise the productivity of several crops. Further, plant breeding programs include prioritizing the productive yield with high doses of added nutrients, to enable the plants to reach their maximum genetic potential. Therefore, there has been a sharp rise in consumption which has become critical to the sustainability of the cropping systems. This means that the major cereals doubled their productivity after the green revolution and could maintain food security, barring a few countries and some plant species (Liu et al., 2015).

However, while the environmental cost was high, the excess fertilizers utilized in the plantations caused a decline in the water and air quality (Zamparas \& Zacharias, 2014). According to mathematical models of production forecasts for crops like maize, wheat, and rice, the amount of nitrogen $(\mathrm{N})$ that the different countries used could be reduced by half while continuing to maintain the productivity (Mueller et al., 2014), thus demonstrating the need for a change in the cultivation system adopted for these crops.

Phosphorus ( $\mathrm{P}$ ) is one of the nutrients used most commonly for the Brazilian crops because of the high deficiency in the soils, usually caused by weathering. Besides, $\mathrm{P}$ is a limited resource, extracted from phosphate rocks which are at the mercy of future geopolitical tensions because the sites of the remaining sources with three-quarters of the world's high-quality reserves are in Morocco (Cordell \& White, 2015).

Potassium (K) acts as a limiting factor in more than $70 \%$ of the terrestrial ecosystems (Sardans \& Peñuelas, 2015), while in the tropical regions, low potassium reserves are usually present. On the contrary, researchers 
purport that $\mathrm{K}$ is principally responsible for drought tolerance, and is essential for the current crops (Rao et al., 2012, Karl et al., 2015).

To boost population growth and achieve higher yields or stabilization of productivity, without excessive fertilizer usage, a new concept of sustainable intensification of agriculture begins to emerge. This is being done to provide new data through research and a policy that simultaneously favors the well-being of several countries (Perniola et al. 2015, Odegard \& Van Der Voet, 2014).

Thus, it is important and necessary to identify the efficiency and responsiveness of the hybrids to the main macronutrients, due to the risk of supply and need to identify the possible cultivars which possess a greater capacity to acquire the nutrients available in the soil, as done earlier in rice (Cancellier et al., 2011) and beans (Lazali et al., 2014).

For vegetable corn cultivation, apart from these aspects, another impediment is the low number of cultivars recommended for the Brazilian market, considered negligible in terms of the number of cultivars destined for grains (Costa et al., 2015). Thus, producers choose to use seeds from hybrids destined for other market niches for the production of vegetable corn, which may have, as a consequence, the obtaining of a product of low quality or that does not meet the requirements consumer market (Rodrigues et al., 2018). The market requires fully grain filled ears, grain moisture between 70 and $80 \%$, free from pest and disease attacks, light cream coloration, well unhusked ears, with a length of more than $15 \mathrm{~cm}$ and a diameter of more than $3 \mathrm{~cm}$ when husked, with a cycle between 90 and 100 days. Besides, companies do not test the potential of the hybrids for fresh consumption linked to their nutritional efficiency. Therefore, it is extremely important the identification of hybrids having greater efficiency and responsiveness, for this niche market.

Thus, the objective of this work was to assess the 10 corn hybrids in terms of their efficiency and responsiveness to $\mathrm{N}, \mathrm{P}$ and $\mathrm{K}$, and identify the ones most suitable for fresh consumption, according to the product type and technological level to be adopted by the farmer.

\section{Method}

\subsection{Local and Experimental Design}

The experiment was carried out at the State University of Goiás, Campus Ipameri, GO, in Dystrophic Red Latosol (Oxisol), is the type of soil present in this region according to the data given in Embrapa (2013). The chemical analysis of the soil is shown in Table 1, without fertilizer, after limestone application and under full fertilization (13/14 and 14/15), based five samples (average). The region experiences tropical humid climate, with distinct dry and rainy seasons (Köppen, 1936). The experiment was conducted between October and December, in the 2013/14 crop and, again during the same period in 2014/15 in the field, according Figure 1. The area was used for the production of vegetable corn for two consecutive crops.

Table 1. Chemical attributes of the soil (0-20 cm depth) after limestone application (2013/14) 2013/14 and 2014/15 crop under full fertilizer. Ipameri, GO, 2019

\begin{tabular}{|c|c|c|c|c|c|c|c|c|c|c|}
\hline Soil & $\mathrm{pH}$ & O.M. & $\mathrm{P}_{\text {resin }}$ & $\mathrm{H}+\mathrm{Al}$ & $\mathrm{Al}^{3+}$ & $\mathrm{K}^{+}$ & $\mathrm{Ca}^{2+}$ & $\mathrm{Mg}$ & CEC & $\mathrm{V}$ \\
\hline & $\mathrm{CaCl}_{2}$ & $\mathrm{~g} \mathrm{dm}^{-3}$ & $\mathrm{mg} \mathrm{dm}{ }^{-3}$ & ------ & - & $---\mathrm{cm}$ & $\mathrm{dm}^{-3}$ & - & -- & $\%$ \\
\hline \multicolumn{11}{|c|}{ Without fertilizer (2013/14 crop) } \\
\hline $0-20 \mathrm{~cm}$ & 5.4 & 22.6 & 3.25 & 2.06 & 0.1 & 0.41 & 2.03 & 0.9 & 3.4 & 64 \\
\hline $20-40 \mathrm{~cm}$ & 4.8 & 18.6 & 1.50 & 3.70 & 0.0 & 0.29 & 1.60 & 0.6 & 2.6 & 40 \\
\hline \multicolumn{11}{|c|}{ With fertilizer-2013/14 crop } \\
\hline $0-20 \mathrm{~cm}$ & 5.2 & 28.3 & 25.7 & 2.2 & 0.0 & 0.75 & 4.7 & 0.9 & 6.3 & 74 \\
\hline $20-40 \mathrm{~cm}$ & 5.0 & 13.5 & 2.5 & 2.1 & 0.0 & 0.58 & 1.8 & 0.5 & 3.3 & 61 \\
\hline \multicolumn{11}{|c|}{ With fertilizer-2014/15 crop } \\
\hline $0-20 \mathrm{~cm}$ & 5.6 & 29.7 & 29.9 & 2.0 & 0.0 & 0.83 & 5.0 & 1.2 & 7.0 & 77 \\
\hline $20-40 \mathrm{~cm}$ & 5.0 & 14.2 & 3.0 & 2.0 & 0.0 & 0.57 & 1.9 & 0.6 & 3.3 & 62 \\
\hline
\end{tabular}

Note. $\mathrm{pH}=$ active acidity; $\mathrm{OM}=$ organic matter; $\mathrm{P}=$ available phosphorus; $\mathrm{H}+\mathrm{Al}=$ potential acidity; $\mathrm{Al}=$ exchangeable acidity; $\mathrm{K}$ = available potassium; $\mathrm{Ca}=$ exchangeable calcium; $\mathrm{Mg}=$ exchangeable magnesium; $\mathrm{CEC}=$ effective cation exchange capacity; $\mathrm{V} \%=$ base saturation a $\mathrm{pH}_{7.0}$. 
Ten hybrids recommended for the Central-West region of Goiás were used. The hybrid AG1051 (double-cross), commercial standard of vegetable corn, and hybrids 2B587PW (single-cross), 2B707PW (single-cross), 30F35HR (single-cross), 30F53YH (single-cross) and P3646H (single-cross) for grain production, and four hybrids, 2B512PW (triple-cross), BRS1055 (single-cross), BM3061 (triple-cross) and P3862YH (single-cross), with the dual capacity for grains and silage were used.

The experiment adopted the completely randomized block design in a $10 \times 3$ (hybrids and doses) factorial scheme, with three replications during the 2013/14 and 2014/15 crops. Each plot comprised four three-meter long rows, spaced $0.5-\mathrm{m}$ apart, with three plants per linear meter. Only the two central rows were utilized, which resulted in a $4-\mathrm{m}^{2}$ usable area.

\subsection{Sowing and Cultural Treatments}

Nine hundred (900) $\mathrm{kg}$ of dolomitic limestone were applied, with 70\% PRNT, mixed and incorporated into the 0-20-m layer (2013/14 crop). After 45 days, conventional soil preparation was commenced with plowing and disking, employing a cultivator to plough the furrows for planting.

Sowing and coverage fertilization were accomplished as recommended for the fresh corn crops, aiming at a yield of between 15,000 and 17,000 kg per hectare of unhusked ears $\left(120 \mathrm{~kg} \mathrm{ha}^{-1} \mathrm{~N}, 120 \mathrm{~kg} \mathrm{ha}^{-1} \mathrm{P}_{2} \mathrm{O}_{5}\right.$ and $90 \mathrm{~kg} \mathrm{ha}^{-1}$ $\mathrm{K}_{2} \mathrm{O}$ ), according to Pereira Filho (2003). Nitrogen was divided into two equal doses; the first was applied during sowing with $\mathrm{P}$ and $\mathrm{K}$ in line, while the second was done 30 days post sowing, in coverage with urea $(45 \% \mathrm{~N})$.
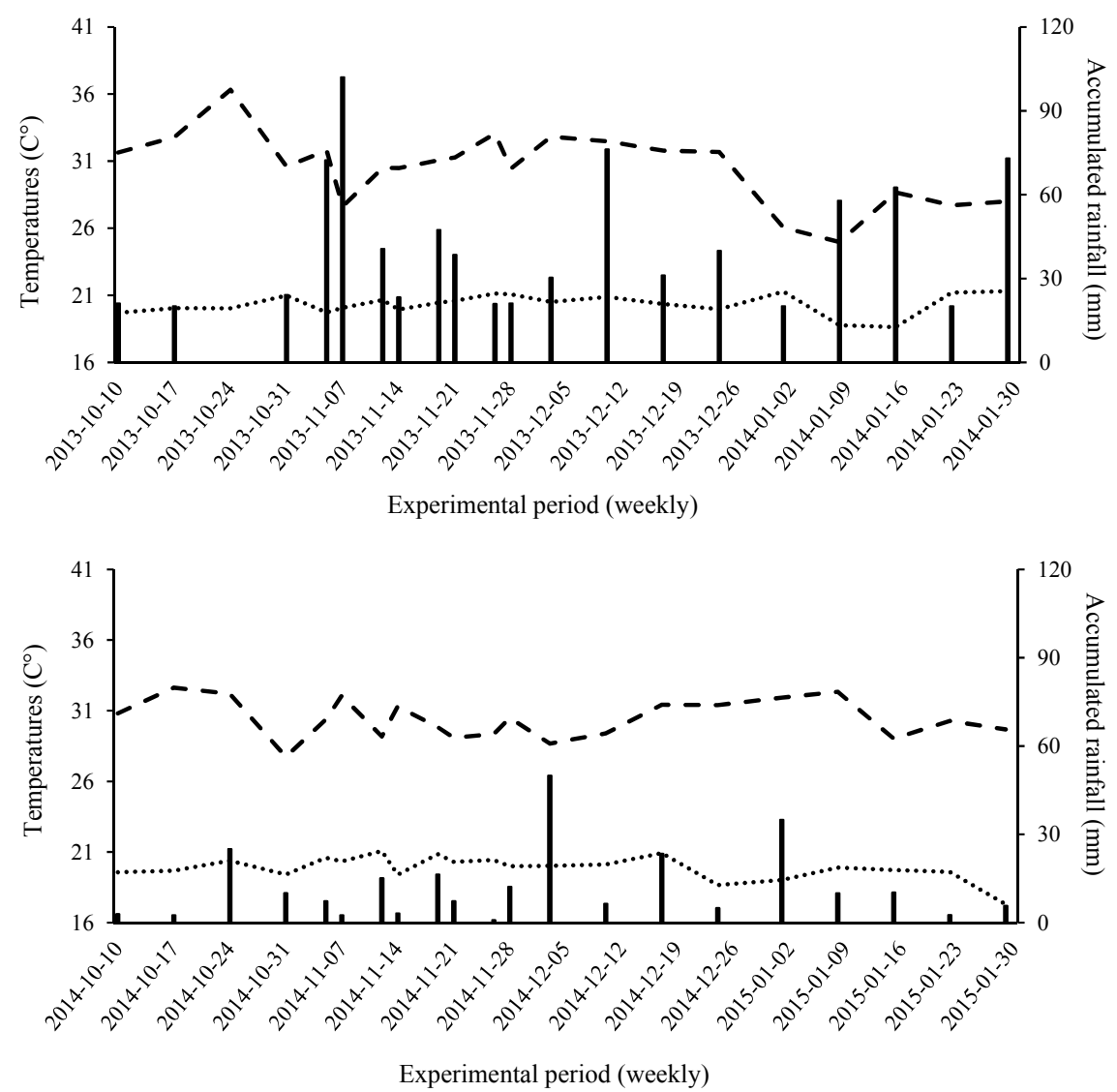

Figure 1. Temperature (--- maximum and $\cdots$ minimum) and accumulated rainfall every 7 days, during the experimental period, in the 2013/14 and 2014/15 crops. Ipameri, GO, 2019

The low availability (without application) and partial were applied in an isolated manner for each nutrient. This implies that under low availability of $\mathrm{N}$ (zero nitrogen applied), only the nutrient present in the soil was considered and $120 \mathrm{~kg} \mathrm{ha}^{-1}$ of $\mathrm{P}_{2} \mathrm{O}_{5}$ (triple superphosphate) and $90 \mathrm{~kg} \mathrm{ha}^{-1}$ of $\mathrm{K}_{2} \mathrm{O}$ (potassium chloride) were applied. Therefore, under partial availability, however, half the recommended dose of $\mathrm{N}$, i.e. $60 \mathrm{~kg} \mathrm{ha}^{-1}$ (urea) was employed (partial). The same procedure was adopted for the $\mathrm{P}\left[0\right.$ (low), 60 (partial) and $120 \mathrm{~kg} \mathrm{ha}^{-1}$ of $\mathrm{P}_{2} \mathrm{O}_{5}$ 
(appropriate dose)] and $\mathrm{K}$ [0 (low), 45 (partial) and $90 \mathrm{~kg} \mathrm{ha}^{-1}$ of $\mathrm{K}_{2} \mathrm{O}$ (appropriate dose)], thus accounting for three different experiments.

Phytosanitary products were then applied using $240 \mathrm{~g} \mathrm{~L}^{-1}$ methoxyfenozide $\left(\operatorname{Intrepid}^{\circledR}\right.$ ), at the $150 \mathrm{~mL} \mathrm{ha}^{-1}$ dose, and beta-cypermethrin (Akito ${ }^{\circledR}$ ) at the $75 \mathrm{~mL} \mathrm{ha}^{-1}$ dose, supported by manual weeding done every three weeks.

Manual harvesting was done when the ears reached the milky stage, $R_{3}$, when the kernels contained $70-80 \%$ of water, around 90 days post planting, which is accepted as the ideal time for commercialization of the produce for fresh use, according to Pereira Filho (2003).

\subsection{Variables and Statistical Analyzes}

Two features related to the sale of the ears were assessed: UEY-unhusked ears yield, obtained by the sum of the total weight of the unhusked ears in the usable area of each plot and then converting it into tons per hectare; MEY-marketable ears yield, obtained by the sum of the weight of the husked ears exceeding $15 \mathrm{~cm}$ in length, with diameter more than $3 \mathrm{~cm}$ across and free from pests and diseases; and RES-agronomic efficiency or responsiveness, calculated by the expression: $\operatorname{RES}=\left(\mathrm{Y}_{\mathrm{a}}-\mathrm{Y}_{\mathrm{b}}\right) /(\mathrm{ANA})$, in $\mathrm{kg} \mathrm{kg}^{-1}$, where $\mathrm{Y}_{\mathrm{a}}$ is the yield with fertilization in kg per hectare, $Y_{b}$ is the yield without fertilizer application in kg per hectare (low availability) or with half of the recommended fertilizer dose in $\mathrm{kg}$ per hectare (partial availability) and, ANA, which represents the difference in the quantity of nutrient added to the soil between the low or partial availability and recommended dose.

The experiment was analyzed using the statistical model, $\mathrm{Y}_{\mathrm{ijkm}}=\mu+\mathrm{G}_{\mathrm{i}}+\mathrm{A}_{\mathrm{j}}+\mathrm{L}_{\mathrm{k}}+(\mathrm{B} / \mathrm{A}) \mathrm{L}_{\mathrm{jkm}}+\mathrm{GA}_{\mathrm{ij}}+\mathrm{GL}_{\mathrm{ik}}+$ $\mathrm{AL}_{\mathrm{jk}}+\mathrm{GAL}_{\mathrm{ijk}}+\varepsilon_{\mathrm{ijkm}}$ where: $\mathrm{G}_{\mathrm{i}}, \mathrm{A}_{\mathrm{j}}, \mathrm{L}_{\mathrm{k}}$ : effect of the hybrids, crops and doses, respectively; $\mathrm{GA}_{\mathrm{ij}}, \mathrm{GL}_{\mathrm{ik}}, \mathrm{AL}_{\mathrm{jk}}$ : effect of the first-order interactions between the hybrids and crops, hybrids and doses, and the crops and doses, respectively; $\mathrm{GAL}_{\mathrm{ijk}}$ : effect of the triple interactions between the hybrids, crops and doses; $(\mathrm{B} / \mathrm{A}) \mathrm{L}_{\mathrm{jkm}}$ : effect of the blocks within the doses and within the crops; and $\varepsilon_{\mathrm{ijkm}}$ : random error, using the GENES software (Cruz, 2013).

\subsection{Classification}

Subsequently, the dispersion plot was constructed to represent and identify the N, P and K efficiency and responsiveness of the corn hybrids, under each specific type of availability (no or partial fertilization), based on the average of the yields of unhusked ears and marketable ears, UEY and MEY, x-axis. Then, based on the average responsivity of these variables, and on the y-axis, according to Cancellier et al. (2011) four categories emerged: efficient and responsive (ER), inefficient and responsive (IR), efficient and non-responsive (ENR), and inefficient and non-responsive (INR), to the three nutrients available.

The hybrids were classification like ER-that present higher yield under low availability and are responsive to increased fertilization; ENR-which present higher yield under low availability but are not responsive to increasing doses; IR-that present low yield values, however, are responsive to increasing doses; INR-which show low performance under low availability and also increased dose.

\section{Results and Discussion}

The base saturation is an excellent indication of the general conditions of soil fertility, being used until as a complement in the nomenclature of the soils. Soils can be divided according to base saturation, in which case the soil would be eutrophic (fertile) $=\mathrm{V} \% \geq 50 \%$. It can be observed in Table 1 that the values obtained in the analyzes are above this value, in the $0-20 \mathrm{~cm}$ layer and close in the $20-40 \mathrm{~cm}$ layer, allowing good conditions for the green corn cultivation and identification of the potential of each hybrid (Table 1).

A significant effect was noted at $1 \%(\mathrm{p}>0.01)$ for the sources of the variation in the Crops (C), Doses (D) and Hybrids $(\mathrm{H})$, besides all the interactions tested (Table 2). The significant effect of the source of the variation in Crops and their respective interactions occurred due to irregular rainfall between the harvests.

According to Llano and Vargas (2015), a large part of the variations observed in the Brazilian productivity is related to the climatic variations that occur during plant development, with greater or lesser influence depending on the region, corresponding to $44 \%$ of the variations expected in the yield. The authors also report that first, the precipitations during the flowering phase exert a greater impact on the yield and that, in the second, but no less important, the average precipitation at each stage of corn development.

The accumulated rainfall during stages $\mathrm{V}_{18}$ and $\mathrm{R}_{3}$, viz., the flowering and beginning of the harvest of the ears, respectively was 286 and $117 \mathrm{~mm}$, with values of average precipitation occurring during the crop cycle of 40 and $12 \mathrm{~mm} \mathrm{day}^{-1}$, in the first and second crops, respectively; therefore, low performance in the second crop is related to the nutritional and water stresses (Figure 1). It is important to report that the 2013/14 crop represents the best 
rainfall index of the region, with little difference between previous harvests and thus allows the identification of more promising hybrids for the southeastern region of Goiás for production vegetable corn.

\subsection{Nitrogen $(N)$}

It is evident in Figure 2 that the identification of the hybrid should be planned with greater emphasis on the product to be marketed. The hybrid 2B587PW (B) would be indicated for farmers possessing higher technological levels and independent of the product (Figure 2). On the contrary, the hybrids AG1051 (F) and 30F53YH (E) under low and partial availability of nitrogen, respectively, would be indicated for producers with low/medium technological level (Figure 2 and 3). The hybrid AG1051 (F) presents high efficiency under conditions of low availability and low responsiveness, for the two crops, indicated possibly for organic or family farming (Figures 2A, 2B, 3A, and 3B). However, performance, in terms of efficiency, drops considerably based on the dose, because when $60 \mathrm{~kg}$ of nitrogen was applied, the hybrid exhibited low performance for efficiency with high responsiveness for the production of vegetable corn (Figures $2 \mathrm{C}$ and 2D).

It can be seen in Figure 2A that the yield of UEY (unhusked ears yield) ranged from 11 to 17 ton $\mathrm{ha}^{-1}$, corresponding to the hybrids P3646H (I) and AG1051 (F), in the 2013/14 crop, however, when the comparison with the 2014/15 crop, Figure 3A, this value is between 6.8 and 10.7 tons ha $^{-1}$, being the average reduction of 5 tons between the harvest, confirming the effect of Indian summer and the low average precipitation verified.

Table 2. Mean square of the variables of the unhusked ears yield (UEY) and marketable ears yield (MEY), under different doses of nitrogen $\left(0,60\right.$ and $120 \mathrm{~kg} \mathrm{ha}^{-1}$ of $\left.\mathrm{N}\right)$, phosphorus $\left(0,60\right.$ and $120 \mathrm{~kg} \mathrm{ha}^{-1}$ of $\left.\mathrm{P}_{2} \mathrm{O}_{5}\right)$ and potassium $\left(0,45\right.$ and $\left.90 \mathrm{~kg} \mathrm{ha}^{-1} \mathrm{~K}_{2} \mathrm{O}\right)$. Ipameri, $\mathrm{GO}, 2019$

\begin{tabular}{|c|c|c|c|c|c|c|c|}
\hline \multirow{2}{*}{ Source of Variation } & \multirow{2}{*}{ DOF } & \multicolumn{2}{|c|}{ Nitrogen } & \multicolumn{2}{|c|}{ Phosphorus } & \multicolumn{2}{|c|}{ Potassium } \\
\hline & & UEY & MEY & UEY & MEY & UEY & MEY \\
\hline & & |---------. & - & ------------- & -1 & - & --------- \\
\hline Crops (C) & 1 & $1067.28^{* *}$ & $198.86^{* *}$ & $1736.71^{* *}$ & $508.02^{* *}$ & $1445.36^{* *}$ & $187.56^{* *}$ \\
\hline Dose (D) & 2 & $1.16^{* *}$ & $17.89^{* *}$ & $114.37^{* *}$ & $55.27^{* *}$ & $81.89^{* *}$ & $104.75^{* *}$ \\
\hline Hybrid (H) & 9 & $11.27^{* *}$ & $6.91^{* *}$ & $14.57^{* *}$ & $8.51^{* *}$ & $16.86^{* *}$ & $8.84^{* *}$ \\
\hline $\mathrm{C} \times \mathrm{D}$ & 2 & $1.19^{* *}$ & $2.14^{* *}$ & $9.50^{* *}$ & $2.84^{* *}$ & $9.53^{* *}$ & $10.14^{* *}$ \\
\hline $\mathrm{C} \times \mathrm{H}$ & 9 & $7.52^{* *}$ & $10.74^{* *}$ & $12.70^{* *}$ & $8.01^{* *}$ & $17.85^{* *}$ & $9.27^{* *}$ \\
\hline $\mathrm{D} \times \mathrm{H}$ & 18 & $4.58^{* *}$ & $3.61^{* *}$ & $2.64^{* *}$ & $2.40^{* *}$ & $2.42^{* *}$ & $2.03^{* *}$ \\
\hline $\mathrm{C} \times \mathrm{D} \times \mathrm{H}$ & 18 & $2.89^{* *}$ & $1.83^{* *}$ & $2.06^{* *}$ & $1.76^{* *}$ & $2.95^{* *}$ & $2.63^{* *}$ \\
\hline Block & 2 & 6.53 & 8.40 & 7.90 & 2.77 & 27.60 & 5.91 \\
\hline Deviation & 118 & 0.14 & 0.27 & 0.54 & 0.26 & 0.69 & 0.22 \\
\hline $\mathrm{CV}(\%)$ & & 3.51 & 9.97 & 7.56 & 10.18 & $7.92^{-}$ & 9.05 \\
\hline
\end{tabular}

Note. Significant at $* 5 \%$ and $* * 1 \%$ probability on $\mathrm{F}$ test; ${ }^{\text {n.s. }}$-non-significant; DOF-degree of freedom; $\mathrm{CV}$ (\%)-coefficient of variation.

The researcher's intention is to identify hybrids that have high efficiency and responsiveness, classified with ER, in this way, can be assigned to different market niches, important to increase the percentage of sales. It is observed that the hybrid P3862YH (J), Figure 3, obtained this performance for UEY (Figures 3A and 3C) and for marketable ears yield (MEY) (Figures 3B and 3D), in the 2014/15 crop, independent of the evaluated nutritional availability, to be able to tolerate flowering water stress in comparison to other hybrids (Figure 1).

According to Aguiar et al., (2008) the operational cost involved to produce grain corn under low nitrogen application is around 785 reais ( \pm 226.90 dollars) per hectare for the hybrid AG1051. However, the increment gained would be low with the increased dosage, with the best cost-benefit ratio, and a value of about $90 \mathrm{~kg} \mathrm{ha}^{-1}$ of nitrogen, in coverage. Thus, it would be indicated for low or medium technological levels. Silva et al. (2014) reported that the increment was continuous, using the same hybrid, although the responsiveness showed a tendency to stabilize from doses above $90 \mathrm{~kg}$ per hectare of nitrogen, confirming the earlier results, with responsiveness of around 69 and $46 \mathrm{~kg} \mathrm{~kg}^{-1}$, using as the base, the variable of the unhusked ears yield, under the identical doses used in the study $\left(0\right.$ and $\left.60 \mathrm{~kg} \mathrm{ha}^{-1}\right)$. 


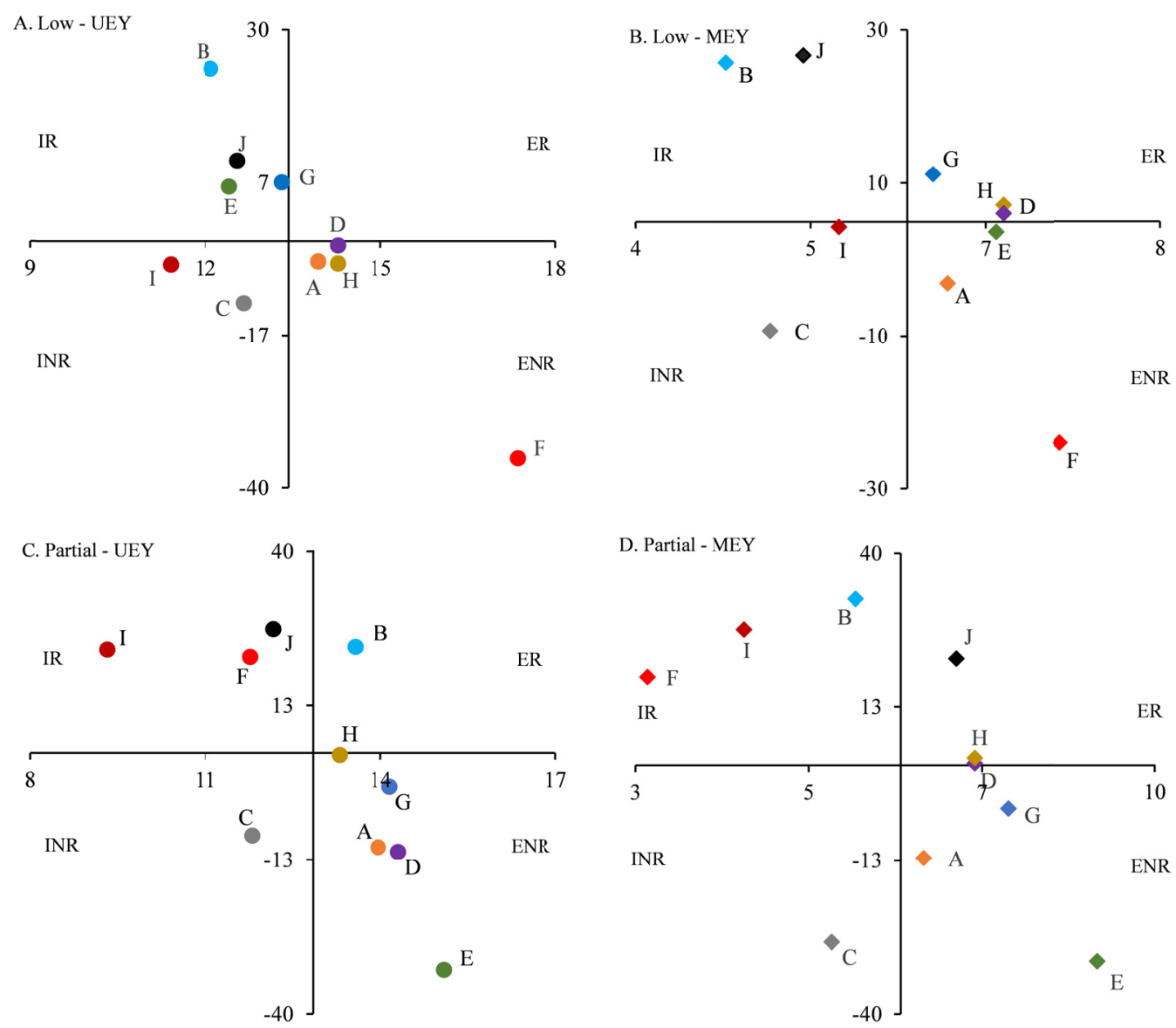

Figure 2. Efficiency (tons) and responsiveness $\left(\mathrm{kg} \mathrm{kg}^{-1}\right)$ of the corn hybrids 2B512PW (A), 2B587PW (B), 2B707PW (C), 30F35HR (D), 30F53YH (E), AG1051 (F), BRS1055 (G), BM3061 (H), P3646H (I) and P3862YH (J) to the unhusked ears yield (UEY) under low (A) and partial availability (C), besides marketable ears yield (MEY) under low (B) and partial availability (D), tested during the 2013/14 crop, as a function of nitrogen. Ipameri, GO, 2019

The criteria for the selection of hybrids among the corn cultivars that were efficient and responsive to nitrogen, from the study of Godoy et al. (2013), were that the genotypes needed to show high repeatability in their performance under low availability nutritional, besides being tested with a large number of cultivars or hybrids, to confirm the yield. The low repeatability among the classifications, based on the crops, has been indicative of the need for assessments in more than just one crop. Further to increase the capacity for identification and the accuracy, the classification, itself should be based on the availability of the nutrient in the soil also, as some of the hybrids maintained their classification among the availability (Figures 2 and 3).

The hybrid 2B707PW (C) presented the INR classification, for the production of vegetable corn, indicating low performance under low $\mathrm{N}$ availability and also to increase fertilization, for the UEY or MEY (Figure 2). However, when compared to other hybrids under water stress besides the nutritional, the hybrid is more efficient and responsive than the some of the test group, especially under low availability (Figure 3). Thus, the indication should be for regions with frequent Indian summer, as was the case of the 2014/15 crop.

It is noteworthy that the combination of different abiotic stresses makes the identification of the most promising hybrids very difficult, as evident from Figures $3 \mathrm{~A}$ and $3 \mathrm{~B}$, which show that most hybrids exhibit very similar behaviors, with only the hybrids AG1051 (F) and BRS1055 (G) showing greater divergence. Under conditions of lowered nitrogen availability, the variability gets increased and performance is greatly altered. Another challenge would be to ascertain the mechanism which supported the enhanced development of the hybrid, such as the higher root volume or more numbers or size of the leaves for example, for the efficient utilization of nitrogen, apart from the mechanism responsible for tolerance to water stress. 

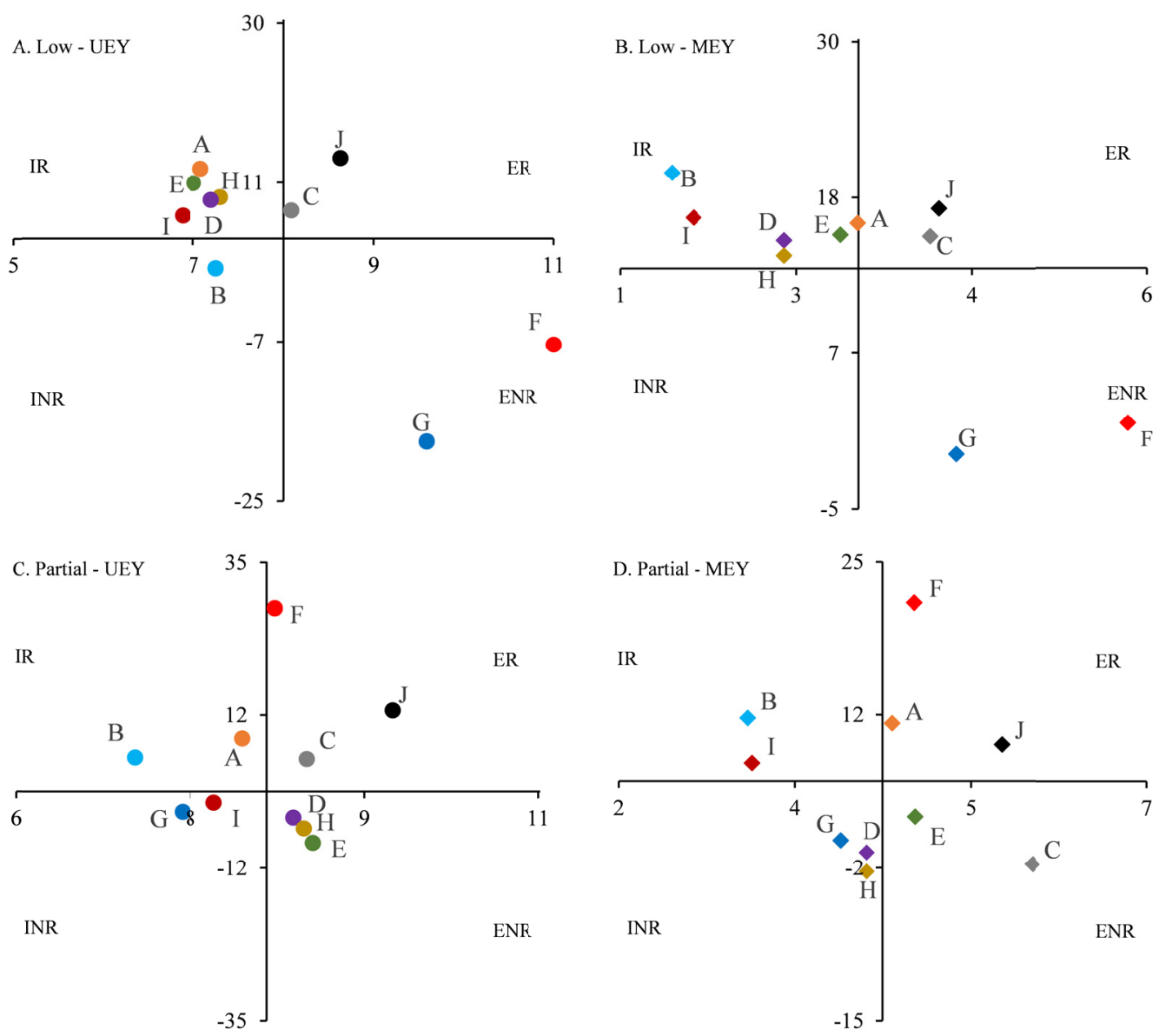

Figure 3. Efficiency (tons) and responsiveness $\left(\mathrm{kg} \mathrm{kg}^{-1}\right)$ of the corn hybrids 2B512PW (A), 2B587PW (B), 2B707PW (C), 30F35HR (D), 30F53YH (E), AG1051 (F), BRS1055 (G), BM3061 (H), P3646H (I) and P3862YH (J) to the unhusked ears yield (UEY) under low (A) and partial availability (C), besides marketable ears yield (MEY) under low (B) and partial availability (D), tested during the 2014/15 crop, as a function of nitrogen. Ipameri, GO, 2019

Jin et al. (2012) reported an increase in the nitrogen doses until the $185 \mathrm{~kg}$ per hectare dose failed to induce a significant rise in the grain yield. Another of their findings was that when more efficient techniques in the cropping system were combined with treatment in the fertilizers, more interesting outcomes were observed. This is because it enabled less use of nitrogen by the corn crop, based on the availability and according to the development; they also reported that the agronomic efficiency showed an inclination to stabilize from this dose.

From the results drawn from the classification of the hybrids, it was necessary to evaluate the hybrids under the conditions of distinct availability, in order to be able to identify the more promising hybrids for each condition, low or partial, besides the improved form of sale of the product. According to Wu et al. (2011) the efficiency of nitrogen expresses a high genotypic and phenotypic correlation with the grain yield and with number of grains per ear, grain weight and chlorophyll index, exhibiting a reliable evaluation of the efficiency and responsiveness of the hybrids, as well as identifying the level of technology to be used for each hybrid.

The most indicated hybrids would be AG1051 (F) under low availability of N and 30F53YH (E) under partial, for the two forms of sale (UEY or MEY), thus, indicated for farmers of low and medium technological level, respectively. Regarding responsiveness, the most indicated hybrids would be 2B587PW (B) and P3862YH (J), regardless of availability or form of sale (Figure 2). When considering the 2014/15 crop, the best-performing under low availability were the hybrids would be AG1051 (F) and BRS1055 (G), and partial 2B707PW (C), P3862YH (J), 30F53YH (E) and AG1051 (F) for the two forms of sale.

To attend higher technological levels would be the P3862YH (J) for low and the AG1051 (F) for partial, considering that the hybrids suffered two types of availability, according to Figures $3 \mathrm{~A}$ and $3 \mathrm{~B}$, after, $3 \mathrm{C}$ and $3 \mathrm{D}$. This demonstrates that caution should be exercised in evaluating the agronomic efficiency, since the application 
of the $60 \mathrm{~kg} \mathrm{ha}^{-1}$ dose promoted the classification change, in this case, indication of the hybrid and the technological level adopted.

\subsection{Phosphorus (P)}

Phosphorus deficiency is one of the most limiting factors in agricultural production across the globe; however, mechanisms that enable the plant to tolerate this deficiency do exist, such as changes in the morphology and root architecture, decrease in the growth rate, higher absorption efficiency and use of phosphorus, and formation of root exudates among others (Aziz et al., 2014).

Plants with a higher number of mechanisms tolerate the low availability of phosphorus in the soil; probably the hybrids 30F53YH (E), AG1051 (F) and BRS1055 (G) for UEY and MEY in low availability of P, in the 2013/14 crop, which possess more numbers of these mechanisms for the production of vegetable corn, serve as the foundation for further studies (Figures 4A and 4B). In partial, the hybrids 30F35HR (D), AG1051 (F), BRS1055 (G) and P3862YH (J) were the ones that presented better performance (Figures 4C and 4D). For the 2014/15 crop, the hybrid 2B512PW (A), 30F53YH (E) and P3862YH (J) for UEY and MEY possibly possessed a higher number of mechanisms for phosphorus and water stresses in combination (Figure 5).
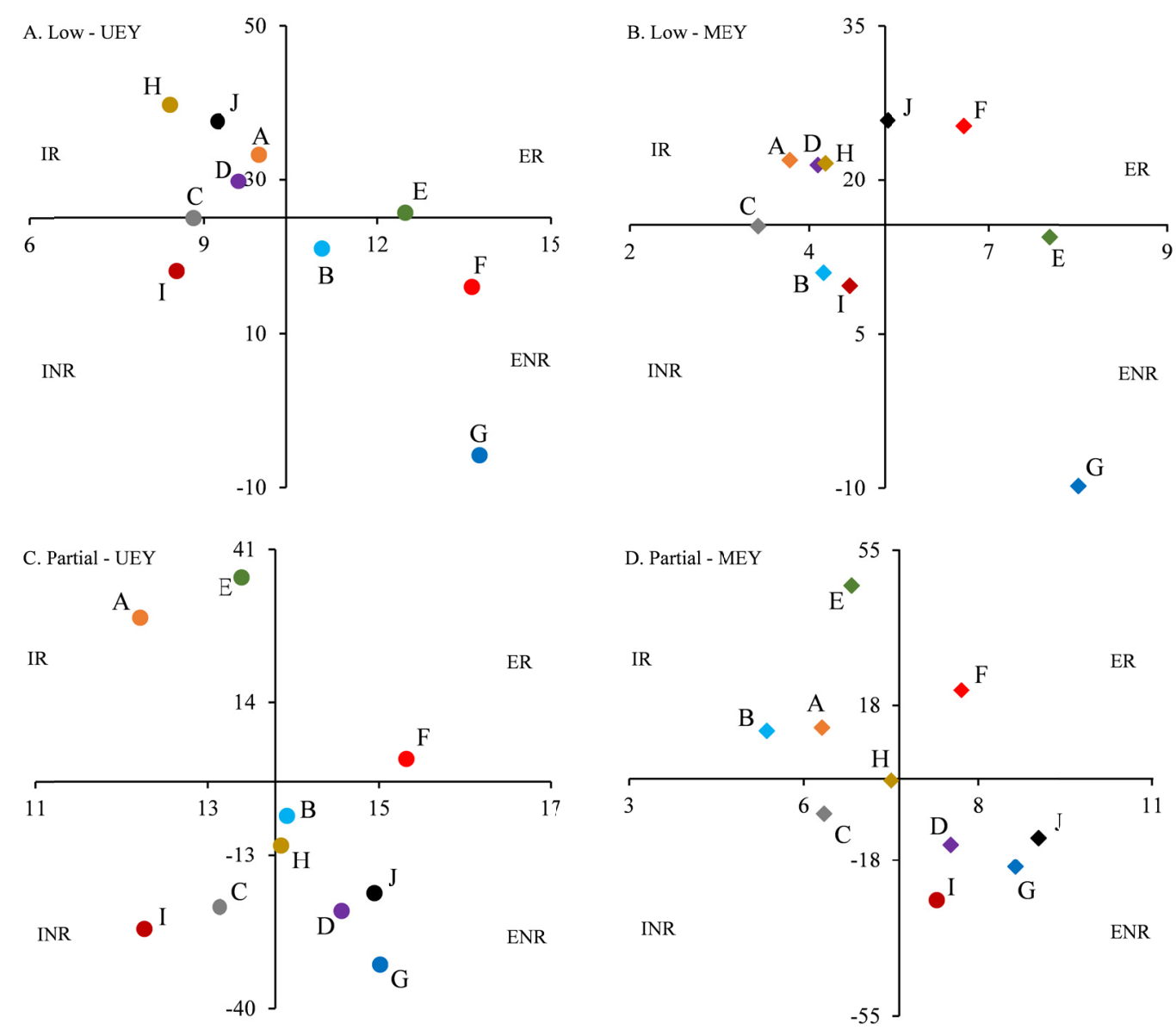

Figure 4. Efficiency (tons) and responsiveness $\left(\mathrm{kg} \mathrm{kg}^{-1}\right)$ of the corn hybrids 2B512PW (A), 2B587PW (B), 2B707PW (C), 30F35HR (D), 30F53YH (E), AG1051 (F), BRS1055 (G), BM3061 (H), P3646H (I) and P3862YH (J) to the unhusked ears yield (UEY) under low (A) and partial availability (C), besides marketable ears yield (MEY) under low (B) and partial availability (D), tested during the 2013/14 crop, as a function of phosphorus. Ipameri, GO, 2019

Souza et al. (2010) studied the relationship of nitrogen and phosphorus to the combining ability and selection of the corn genotypes with the application of $30 \mathrm{~kg}$ per hectare of $\mathrm{P}_{2} \mathrm{O}_{5}$; however, for example if the dose was changed to $60 \mathrm{~kg} \mathrm{ha}^{-1}$, it could trigger a change in the entire classification of the lines as well as in the effects expressed in the 
general and specific combining ability. In such a case, another crop (harvest) is indicated to validate the gene effects in specific doses.

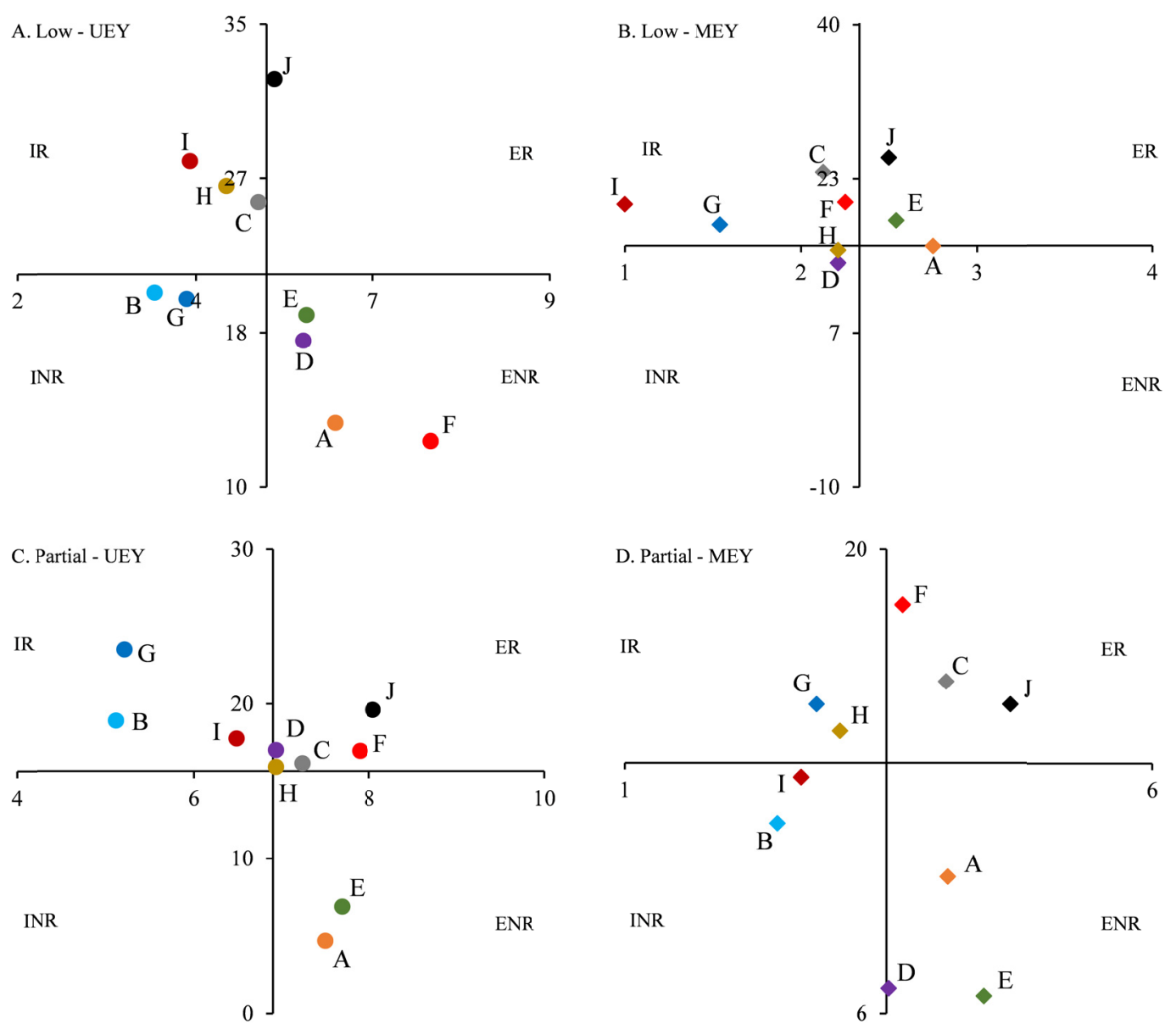

Figure 5. Efficiency (tons) and responsiveness $\left(\mathrm{kg} \mathrm{kg}^{-1}\right)$ of the corn hybrids 2B512PW (A), 2B587PW (B), 2B707PW (C), 30F35HR (D), 30F53YH (E), AG1051 (F), BRS1055 (G), BM3061 (H), P3646H (I) and $\mathrm{P} 3862 \mathrm{YH}(\mathrm{J})$ to the unhusked ears yield (UEY) under low (A) and partial availability (C), besides marketable ears yield (MEY) under low (B) and partial availability (D), tested during the 2014/15 crop, as a function of phosphorus. Ipameri, GO, 2019

The highest responsive effect was exhibited by the hybrid 30F53YH (E-30.6 $\left.\mathrm{kg} \mathrm{kg}^{-1}\right)$ in the $2013 / 14 \mathrm{crop}$, and by the P3862YH (J-23.1 kg kg$\left.{ }^{-1}\right)$, in the 2014/15 crop, both for UEY and MEY, being indicated for farmers with technology of medium to high levels (Figure 5). However, these values may rise with the use of polymer-coated phosphorus, which according to Almeida et al. (2016) increases the dry matter yield and, indeed, its responsiveness, when compared with simple superphosphate, due to its availability throughout the crop development cycle.

The high specificity observed in the hybrids for P makes it difficult to indicate the most favorable hybrid to multiple environments or market. For example, the hybrid 2B512PW (A) has medium to high responsiveness, however, efficiency is among the lowest in the group, regardless of how it is sold (Figure 4). However, its efficiency increases, and its responsive effect falls when compared to the group in the next crop (Figure 5).

Similar to the response to nitrogen, phosphorus responsiveness also tends to stabilize from the $90 \mathrm{~kg}$ per hectare dose of $\mathrm{P}_{2} \mathrm{O}_{5}$, according to the results of Fontoura et al. (2010). The authors observed similar behavior in the no-tillage system, where the reactive and soluble natural phosphates do not induce any significant difference in grain yield, indicating similar agronomic efficiency. Also, according to Castro et al. (2016) the $94 \mathrm{~kg}$ per hectare dose would be the most indicated, with yield reduction noted around the $120 \mathrm{~kg}$ per hectare dose of $\mathrm{P}_{2} \mathrm{O}_{5}$, aiming at 
grain production. However, the dose reduction to marketable ears yield (MEY), could increase the number of ears unsuitable for the consumer market and reduce the observed responsiveness.

The hybrids 2B707PW (C) and P3646H (I), in the 2013/14 crop, have low agronomic efficiency, as well as low capacity to acquire P present in the soil, and are not indicated for the production of vegetable corn (UEY or MEY), according to Figures 4A to 4D. This same performance was observed for BRS1055 (G) hybrids, for efficiency, and for responsiveness in 2B512PW (A), 30F35HR (D) and 30F53YH (E), with few exceptions (Figure 5).

Based on the 2013/14 crop, due to its similarity with the previous harvests as reported above, the most indicated hybrids would be the 30F53YH (E), AG1051 (F) and BRS1055 (G) that present the highest efficiency (low technological level), under low $\mathrm{P}$ availability, and can be sold under both forms (Figures 4A and 4B). For an intermediate level, the hybrids 30F35HR (D), AG1051 (F), BRS1055 (G) and P3862YH (J) would be the most suitable for the market (Figures 4C and 4D). On the other hand, for the responsiveness (high technological level), the 2B512PW (A), 30F53YH (E) and AG1051 (F) hybrids showed better performance (Figure 4).

\subsection{Potassium $(K)$}

Potassium, out of the three nutrients investigated and discussed, has the fewest number of studies focused on nutritional efficiency. Petter et al. (2016) reported a higher agronomic efficiency for grain yield when the K was split into two doses, in which $50 \%$ of the recommended dose was administered at sowing and the remaining $50 \%$ at 30 days post sowing, with a $29 \%$ higher value than the treatment used in this work. After this, the treatment with the total dose being applied at 30 days post sowing. Followed by the treatments total sowing and with the same performance of the dose $50 \%$ with 20 days and $50 \%$ with 40 days after sowing, being the agronomic efficiency calculated based on low availability of the potassium.

The high responsiveness shown by the 2B512PW (A) and 30F53YH (E) hybrids for the two forms of sale in the 2013/14 crop indicates the potential of these hybrids to serve medium/high level farmers for the production of vegetable corn. For the low level, the most suitable hybrids would be 30F35HR (D) and BRS1055 (G), with small responsive effect and not indicated for farmers who want to improve technology due to this fact (Figure 6).

For the potassium, the 30F35HR (D) and BRS1055 (G) hybrid ranks among the most efficient under conditions of low availability (Figures 6A and 6B) and partial availability (Figures 6C and 6D), indicating that its nutritional characteristics and other significant variables should be investigated to identify the mechanisms present. Potassium increases the protein and amino acid content of the grains (Pettigrew, 2008), apart from the photosynthetic rate, plant height and ear insertion, number of rows and number of grains per row (Rodrigues et al., 2014), all of which are highly important for the commercialization of vegetable corn, mainly in the form of a tray. This simply implies that in the field, the plants possessing greater efficiency to the potassium can exhibit increased biomass, are easier to harvest and also have ears with higher nutritional values. All these features contribute towards the production of more nutritious and superior quality of food for the consumer.

On considering the 2014/15 crop, the most responsive as well as the most highly efficient was the P3862YH (J) hybrid, with the potassium responsiveness exceeding that of the hybrids investigated, thus indicated for all levels of technology and independent of the product (Figure 7).

For efficiency, the 2B512PW (A), 2B707PW (C), 30F53YH (E), AG1051 (F), hybrids also exhibit a better performance for UEY and MEY (Figure 7). However, characterization of the water deficit is highly complex because it involves the differences between the places, crops and, apart from these effects, the indirect effects induced by fungi, high temperatures, as well as fertility as reported by Paterniani et al. (2015), making it difficult to identify the best hybrid. Bukhsh et al. (2012) reaffirm that the potassium application not only improves the grain yield, but also the quality characters, as well as a more judicious use of water and ability to tolerate drought. Thus, greater potassium efficiency may also indirectly promote the identification of plants that can better tolerate water stress.

Hybrids showed a higher potassium-responsive effect, compared to nitrogen and phosphorus, respectively, mainly for MEY in the two crops, according to Figures 2, 3, 4, 5, 6 and 7, not corresponding to the findings of $\mathrm{Xu}$ et al. (2014). The researchers studied a set of data from 2000 to 2010 in the main corn producing areas of China and classified the importance of the responsiveness of $\mathrm{P}>\mathrm{K}>\mathrm{N}$, respectively, based on the increase observed in the agronomic efficiency of these nutrients. This demonstrates the possibility of minimizing fertilizers in modern agriculture and can be an example for the conditions of agriculture in Brazil in the future.

\subsection{Multiple Indication to $\mathrm{N}-\mathrm{P}-\mathrm{K}$}

Regarding the simultaneous behavior of the three macronutrients, the use of the two crops, 2013/14 and 2014/15 for the selection of the best performing hybrid, is not feasible due to the divergent behavior verified in the 
analyzes (Table 2) and confirmed by the Figures (Figures 2, 3, 4, 5, 6 and 7), presented above. Thus, the indication of greater efficiency and responsiveness (ER), in a joint manner, was performed by crops and based on the best performance hybrids by availability and subsequently by the form of sale, due to lower classification change. It is pointed out that the $2013 / 14$ crop represents better the rainfall present in the region, so the hybrids of this crop are the most suitable to be indicated to the farmers.
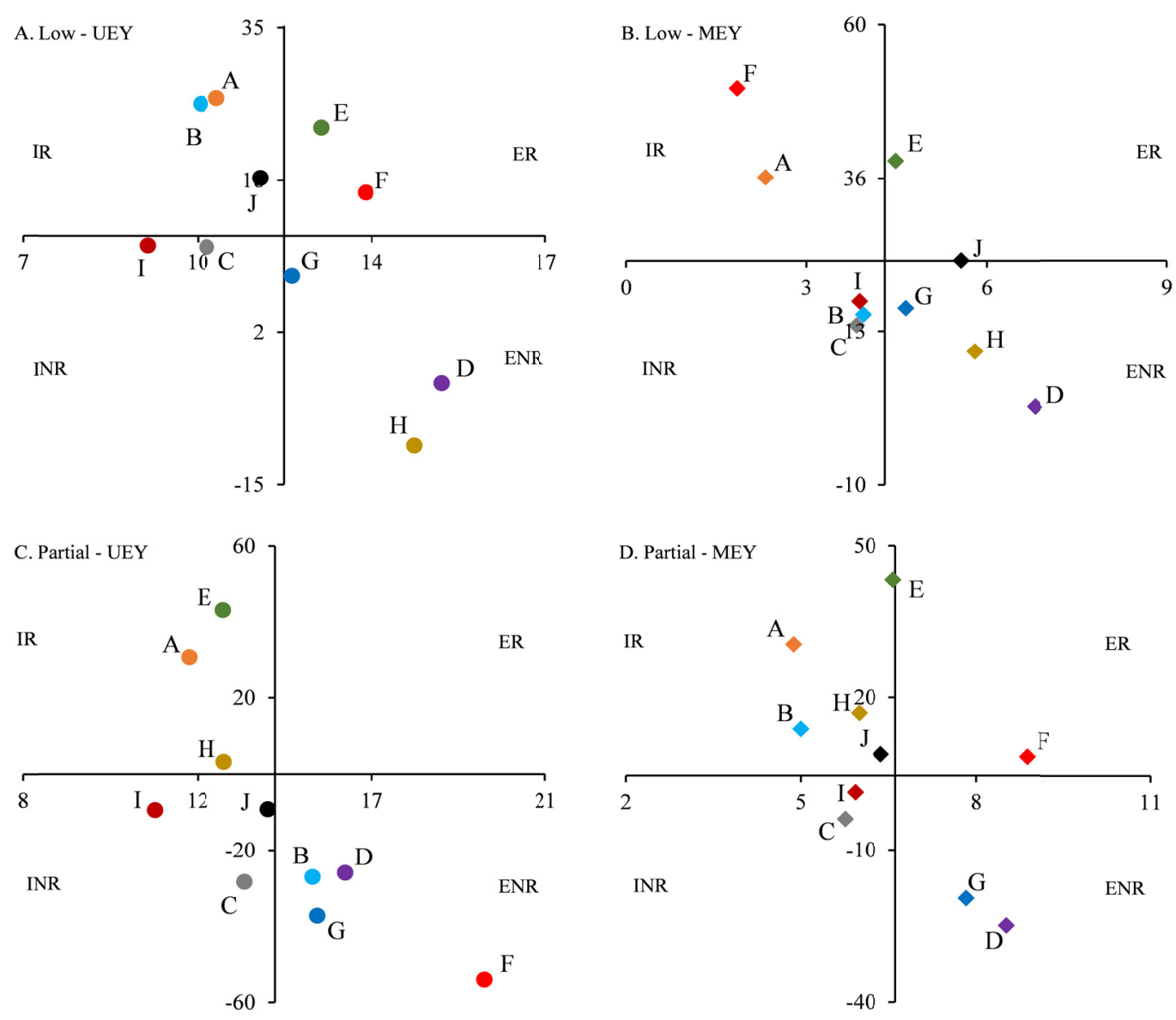

Figure 6. Efficiency (tons) and responsiveness $\left(\mathrm{kg} \mathrm{kg}^{-1}\right)$ of the corn hybrids 2B512PW (A), 2B587PW (B), 2B707PW (C), 30F35HR (D), 30F53YH (E), AG1051 (F), BRS1055 (G), BM3061 (H), P3646H (I) and P3862YH (J) to the unhusked ears yield (UEY) under low (A) and partial availability (C), besides marketable ears yield (MEY) under low (B) and partial availability (D), tested during the 2013/14 crop, as a function of potassium. Ipameri, GO, 2019

If an analysis is performed, disregarding the form of sale of the ears and the type of nutritional availability (low or partial), and considering as the focus the technological level to be adopted by the farmer, the most efficient hybrid to N, P and K were simultaneously hybrid BRS1055 (G), according to Figures 2, 4 and 6, as well as the hybrid 30F35HR (D), with the exception of UEY and MEY, in low P availability (Figures 4A and 4B), for the 2013/14 crop. These hybrids would be indicated for producers with low to medium technological levels.

The P3862YH (J) hybrid showed high performance for agronomic efficiency (responsive) for N, P and K, with the restriction for some availabilities, mainly for $\mathrm{P}$ (Figures $4 \mathrm{C}$ and $4 \mathrm{D}$ ) and for K, in UEY under partial (Figure 6C). In this case, indicated for farmers with higher technological level or who seek to improve the technology present in the crop.

For the 2014/15 crop, the P3862YH (J) was the hybrid with medium or high combined efficiency high responsiveness to the macronutrients, together (Figures 3,5 and 7), indicating the potential of this hybrid for regions with low rainfall index and low-level farmers. It is verified that the hybrid 2B512PW (A) has superior performance for the different availabilities, both low and partial, except for UEY under the two $\mathrm{N}$ availabilities (Figures 3A and 3C). In addition to the hybrids AG1051 (F) and 2B707PW (C), which presented high efficiency, 
except for MEY in P (Figure 5B), for the first hybrid, and UEY and MEY in P, for second (Figures 5A and 5B). Although it is possible to classify the hybrids under different conditions of rainfall, the hybrid capable of tolerating nutritional and water stress must be evaluated more carefully, especially in relation to the water control.
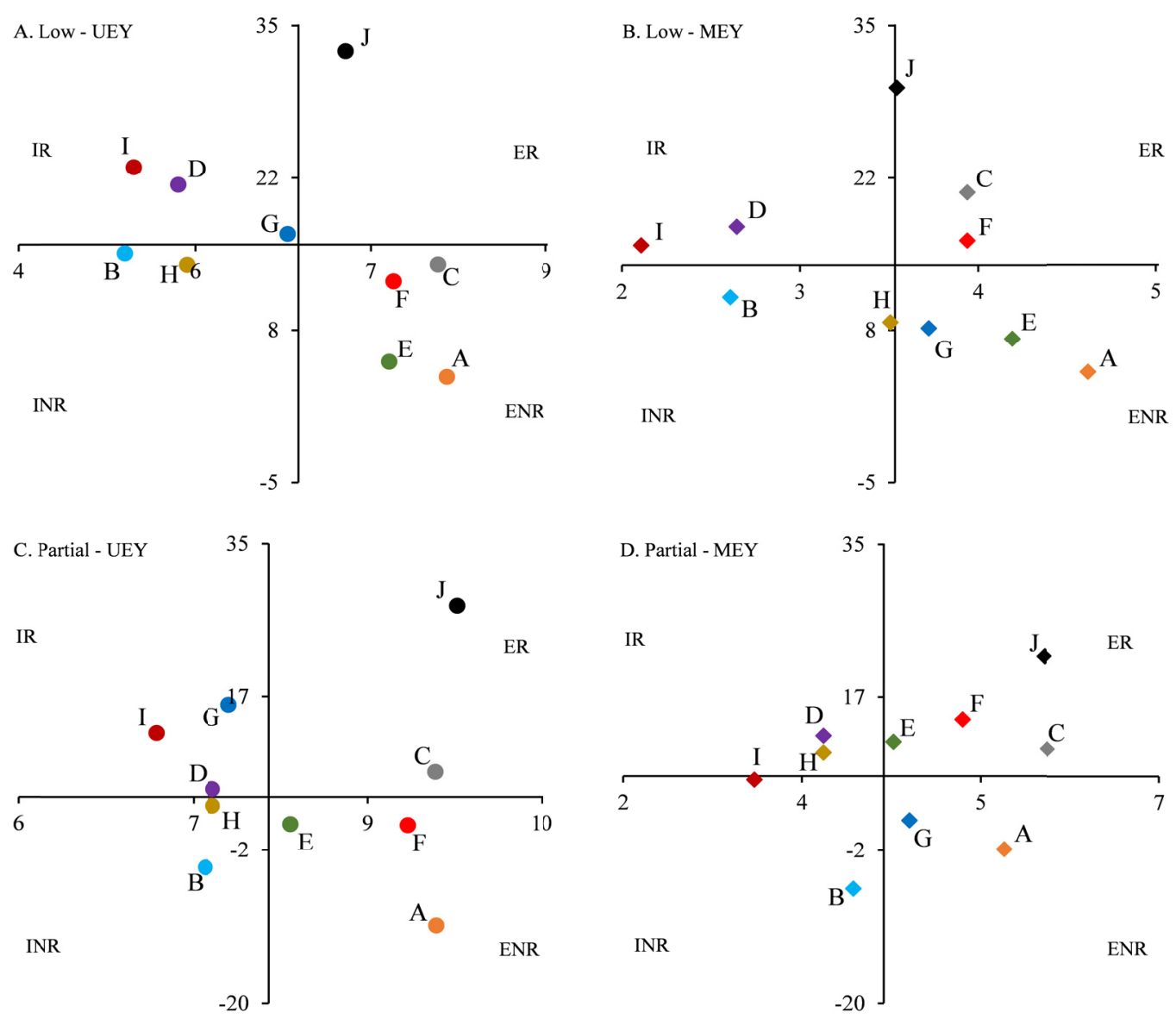

Figure 7. Efficiency (tons) and responsiveness $\left(\mathrm{kg} \mathrm{kg}^{-1}\right)$ of the corn hybrids 2B512PW (A), 2B587PW (B), 2B707PW (C), 30F35HR (D), 30F53YH (E), AG1051 (F), BRS1055 (G), BM3061 (H), P3646H (I) and P3862YH (J) to the unhusked ears yield (UEY) under low (A) and partial availability (C), besides marketable ears yield (MEY) under low (B) and partial availability (D), tested during the 2014/15 crop, as a function of potassium. Ipameri, GO, 2019

The most efficient and responsive hybrid must first be identified in isolation, based on the availability it is subjected to and later, by its sale, focused on fresh consumption. On the other hand, the simultaneous, has values between medium to high, with this, the indication or the study to better use the mechanisms present in the hybrids should be done with caution, according to the combinations between the availability and the desired form of sale.

\section{Conclusion}

For farmers of low technological level, the most indicated hybrids are 30F35HR, BM3061, 2B512PW under low nitrogen availability. For the phosphorus are hybrids BRS1055 and AG1051, and with respect to potassium are the hybrids 30F35HR and BRS1055 for the production of corn for fresh consumption, under both forms of sale.

Based on the agronomic efficiency of nitrogen, the hybrids 2B587PW and P3862YH are the most indicated for medium or high level farmers. For phosphorus and potassium, simultaneously the hybrids $2 \mathrm{~B} 512 \mathrm{PW}$ and 30F53YH for the production of vegetable corn, regardless for the two forms of sale.

The hybrids indicated for low or partial availability (low technological level) were BRS1055 and 30F35HR, with respect to agronomic efficiency or responsiveness, the hybrid P3862YH was the one that presented the best 
performance and indicated for technological levels of medium to high, considering the classification obtained for the nitrogen, phosphorus, and potassium for the production of vegetable corn unhusked or not (marketable ears).

\section{References}

Aguiar, R. A., Silveira, P. M., Moreira, J. A. A., \& Wander, A. E. (2008). Análise econômica de diferentes práticas culturais na cultura do milho (Zea mays L.). Pesquisa Agropecuária Tropical, 38(4), 241-248.

Almeida, T., Pocojeski, E., Nunes C. N., Oliveira, P. M., \& Silva, L. S. (2016). Eficiência de fertilizante fosfatado protegido na cultura do milho. Scientia Agraria, 17(1), 29-35. https://doi.org/10.5380/ rsa.v17i1.46173

Aziz, T., Sabir, M., Farooq, M., Maqsood, M. A., Ahmad, H. R., \& Warraich, E. A. (2014). Phosphorus deficiency in plants: Responses, adaptive mechanisms, and signaling. Springer India, 1, 133-148. https://doi.org/10.1007/978-81-322-1542-4_7

Bukhsh, M. A. A. H. A., Ahmad, R., Iqbal, J., Maqbool, M. M., Ali, A., Ishaque, M., \& Hussain, S. (2012). Nutritional and physiological significance of potassium application in maize hybrid crop production. Pakistan Journal of Nutrition, 11(2), 187-202. https://doi.org/10.3923/pjn.2012.187.202

Cancellier, E. L., Barros, H. B., Kischel, E., Gonzaga, L. A. D. M., Brandão, D. R., \& Fidelis, R. R. (2011). Eficiência agronômica no uso de nitrogênio mineral por cultivares de arroz de terras altas. Revista Brasileira de Ciências Agrárias, 6(4), 650-656. https://doi.org/10.5039/agraria.v6i4a1420

Castro, L. R., Reis, T. C., Júnior, O. F., Almeida, R. B. S., \& Alves, D. S. (2017). Diferentes doses de fósforo e formas de aplicação na cultura do milho, em barreiras-Bahia. Agrarian, 9(31), 47-54.

Cordell, D., \& White, S. (2015). Tracking phosphorus security: Indicators of phosphorus vulnerability in the global food system. Food Security, 7(2), 337-350. https://doi.org/10.1007/s12571-015-0442-0

Costa, F. R., Damaso, L. F., Mendes, R. C., Marques, D. D., \& Rodrigues, F. (2015). Desempenho de híbridos de milho para consumo in natura em diferentes doses de nitrogênio. Científica, 43(2), 109-116. https://doi.org/10.15361/1984-5529.2015v43n2p109-116

Cruz, C. D. (2013). GENES - A software package for analysis in experimental statistics and quantitative genetics. Acta Scientiarum, 35(3), 271-276. https://doi.org/10.4025/actasciagron.v35i3.21251

EMPRAPA. (2013). Classificação Brasileira De Solos (3rd ed.). Centro Nacional de Pesquisa de Solos.

Fontoura, S. M. V., Vieira, R. C. B., Bayer, C., Ernani, P. R., \& Moraes, R. P. (2010). Eficiência técnica de fertilizantes fosfatados em Latossolo sob plantio direto. Revista Brasileira de Ciência do Solo, 34(6), 1908-1914. https://doi.org/10.1590/S0100-06832010000600015

Godoy, C. L., Miranda, G. V., DeLima, R. O., Souza, L. V., Galvão, J. C. C., \& Santos, I. C. D. (2013). Methods to classify maize cultivars in use efficiency and response to nitrogen. Revista Ceres, 60(5), 699-705. https://doi.org/10.1590/S0034-737X2013000500014

Jin, L., Cui, H., Li, B., Zhang, J., Dong, S., \& Liu, P. (2012). Effects of integrated agronomic management practices on yield and nitrogen efficiency of summer maize in North China. Field Crops Research, 134, 30-35. https://doi.org/10.1016/j.fcr.2012.04.008

Karl, T. R., Arguez, A., Huang, B., Lawrimore, J. H., McMahon, J. R., Menne, M. J., \& Zhang, H-M. (2015). Possible artifacts of data biases in the recent global surface warming hiatus. Science, 348(6242), 1469-1472. https://doi.org/10.1126/science.aaa5632

Köppen, W. (1936). Das geographische System der Klimate. In W. Köppen, \& R. Geiger (Eds.), Handbuch der Klimatologie. Berlin: Gebrüder Bornträger.

Lazali, M., Bargaz, A., Carlsson, G., Ounane, S. M., \& Drevon, J. J. (2014). Discrimination against ${ }^{15} \mathrm{~N}$ among recombinant inbred lines of Phaseolus vulgaris L. contrasting in phosphorus use efficiency for nitrogen fixation. Journal of Plant Physiology, 171(3-4), 199-204. https://doi.org/10.1016/j.jplph.2013.07.009

Liu, Y., Pan, X., \& Li, J. (2015). A 1961-2010 record of fertilizer use, pesticide application and cereal yields: A review. Agronomy for Sustainable Development, 35(1), 83-93. https://doi.org/10.1007/s13593-014-0259-9

Llano, M. P., \& Vargas, W. (2015). Climate characteristics and their relationship with soybean and maize yields in Argentina, Brazil and the United States. International Journal of Climatology, 36, 1471-1483. https://doi.org/10.1002/joc.4439 
Mueller, N. D., West, P. C., Gerber, J. S., MacDonald, G. K., Polasky, S., \& Foley, J. A. (2014). A tradeoff frontier for global nitrogen use and cereal production. Environmental Research Letters, 9(5), 01-08. https://doi.org/10.1088/1748-9326/9/5/054002

Odegard, I. Y. R., \& Van der Voet, E. (2014). The future of food-Scenarios and the effect on natural resource use in agriculture in 2050. Ecological Economics, 97, 51-59. https://doi.org/10.1016/j.ecolecon.2013.10.005

Paterniani, M. E. A. G. Z., Guimarães, P. S., Bernini, C. S., \& Gallo, P. B. (2015). Caracteres secundários relacionados à tolerância à seca em progênies de irmão germanos interpopulacionais de milho. Revista Brasileira de Milho e Sorgo, 14(1), 130-144. https://doi.org/10.18512/1980-6477/rbms.v14n1p130-144

Pereira Filho, I. A. (2003). O cultivo do milho verde. EMBRAPA Milho e Sorgo, Sete Lagoas, MG, Brasil.

Perniola, M., Lovelli, S., Arcieri, M., \& Amato, M. (2015). Sustainability in Cereal Crop Production in Mediterranean Environments. Springer International Publishing, 1, 15-27. https://doi.org/10.1007/978-3319-16357-4_2

Petter, F. A., Andrade, F. R., Zuffo, A. M., Sousa, M. M. M., Pacheco, L. P., \& Almeida, F. A. (2016). Doses e épocas de aplicação de potássio no desempenho agronômico do milho no cerrado piauiense. Comunicata Scientiae, 7(3), 372-382. https://doi.org/10.14295/cs.v7i3.1218

Pettigrew, W. T. (2008). Potassium influences on yield and quality production for maize, wheat, soybean and cotton. Physiologia Plantarum, 133(4), 670-681. https://doi.org/10.1111/j.1399-3054.2008.01073.x

Rao, S. R., Qayyum, A., Razzaq, A., Ahmad, M., Mahmood, I., \& Sher, A. (2012). Role of foliar application of salicylic acid and L-tryptophan in drought tolerance of maize. Journal of Animal \& Plant Sciences, 22(3), 768-772.

Rodrigues, F., Melo, P. G. S., Resende, C. L. P., Mrojinski, F., Mendes, R. C., \& Silva, M. A. (2018). Aptidão de híbridos de milho para o consumo in natura. Revista de Ciências Agrárias, 41(2), 484-492. https://doi.org/ 10.19084/RCA17216

Rodrigues, M. A. C., Buzetti, S., Teixeira Filho, M. C. M., Garcia, C. M. P., \& Andreotti, M. (2014). Adubação com KCl revestido na cultura do milho no Cerrado. Revista Brasileira Engenharia Agrícola e Ambiental, 18(2), 127-133. https://doi.org/10.1590/S1415-43662014000200001

Sardans, J., \& Peñuelas, J. (2015). Potassium: A neglected nutrient in global change. Global Ecology and Biogeography, 24(3), 261-275. https://doi.org/10.1111/geb.12259

Silva, G. F., Oliveira, F. H. T., Pereira, R. G., Diógenes, T. B. A., Júnior, J. N., \& Souza Filho, A. L. (2014). Doses de nitrogênio e de fósforo recomendadas para produção econômica de milho verde em Mossoró-RN. Magistra, 26(4), 467-481.

Souza, L. V., Miranda, G. V., Galvão, J. C. C., DeLima, R. O., Guimarães, L. J. M., Eckert, F. R., \& Mantovani, É. E. (2015). Inter-relações de nitrogênio e fósforo na capacidade de combinação e na seleção em milho. Ceres, 57(5), 633-641. https://doi.org/10.1590/S0034-737X2010000500011

Wu, Y., Liu, W., Li, X., Li, M., Zhang, D., Hao, Z., ... Xie, C. (2011). Low-nitrogen stress tolerance and nitrogen agronomic efficiency among maize inbreds: Comparison of multiple indices and evaluation of genetic variation. Euphytica, 180(2), 281-290. https://doi.org/10.1007/s10681-011-0409-y

Xu, X., He, P., Pampolino, M. F., Johnston, A. M., Qiu, S., Zhao, S., ... Zhou, W. (2014). Fertilizer recommendation for maize in China based on yield response and agronomic efficiency. Field Crops Research, 157, 27-34. https://doi.org/10.1016/j.fcr.2013.12.013

Zamparas, M., \& Zacharias, I. (2014). Restoration of eutrophic freshwater by managing internal nutrient loads: A review. Science of the Total Environment, 496, 551-562. https://doi.org/10.1016/j.scitotenv.2014.07.076

\section{Copyrights}

Copyright for this article is retained by the author(s), with first publication rights granted to the journal.

This is an open-access article distributed under the terms and conditions of the Creative Commons Attribution license (http://creativecommons.org/licenses/by/4.0/). 